\title{
HUBUNGAN KETERAMPILAN MEMBACA FIKSI DENGAN KETERAMPILAN MENULIS CERPEN SISWA KELAS IX SMP NEGERI 1 KECAMATAN PANGKALAN
}

oleh

\author{
Rani Ardesi Pratiwi \\ Dosen Program Studi Pendidikan Bahasa Indonesia, FT Universitas Malikussaleh \\ Surel: raniardesip@unimal.ac.id
}

\begin{abstract}
ABSTRAK
Penelitian ini bertujuan: (1) mendapatkan deskripsi mengenai keterampilan membaca fiksi siswa kelas IX SMP Negeri 1 Kecamatan Pangkalan, (2) mendapatkan deskripsi mengenai keterampilan menulis cerpen siswa kelas IX SMP Negeri 1 Kecamatan Pangkalan, (3) menganalisis hubungan keterampilan membaca fiksi dengan keterampilan menulis cerpen siswa kelas IX SMP Negeri 1 Kecamatan Pangkalan. Jenis penelitian yang digunakan adalah kuantitatif dengan desain korelasional. Metode dalam penelitian ini ialah deskriptif analisis. Subjek penelitian ini adalah siswa kelas IX SMP Negeri 1 Kecamatan Pangkalan dengan jumlah 164 siswa. Sampel diambil 20\% dari 164 siswa yaitu 34 siswa menggunakan teknik Proportional Random Sampling. Berdasarkan hasil analisis data dan pembahasan disimpulkan hal-hal berikut ini. Pertama, keterampilan membaca fiksi siswa kelas IX SMP Negeri 1 Kecamatan Pangkalan berada pada kualifikasi cukup (61,42). Kedua, keterampilan menulis cerpen siswa kelas IX SMP Negeri 1 Kecamatan Pangkalan berada pada kualifikas cukup $(60,37)$. Ketiga, terdapat hubungan yang signifikan antara keterampilan membaca fiksi dengan keterampilan menulis cerpen siswa kelas IX SMP Negeri 1 Kecamatan Pangkalan.
\end{abstract}

Kata Kunci: hubungan, membaca, fiksi, menulis, cerpen

\section{PENDAHULUAN}

Ruang lingkup pembelajaran Bahasa dan Sastra Indonesia terdiri atas empat keterampilan, yakni keterampilan mendengarkan, berbicara, membaca dan menulis. Keterampilan menulis dan berbicara merupakan keterampilan berbahasa yang sifatnya produktif (menghasilkan), sedangkan keterampilan mendengarkan dan membaca merupakan keterampilan berbahasa yang sifatnya reseptif (menerima).

PBM (Proses Belajar Mengajar) yang dilakukan di sekolah menuntut siswa memiliki keterampilan yang baik dalam hal menulis dan membaca. Semi (2007:14) mendefinisikan bahwa menulis adalah suatu proses kreatif untuk memindahkan gagasan ke dalam bentuk bahasa tulis. Tarigan menambahkan (2008:22) bahwa menulis adalah suatu kegiatan yang dilakukan dengan cara melukiskan lambang-lambang grafik yang menggambarkan suatu bahasa, dapat dibaca, dan dipahami oleh orang lain. Jadi, dari pendapat yang telah dikemukakan 
oleh ahli di atas, dapat disimpulkan bahwa menulis merupakan serangkaian kegiatan yang dilakukan untuk memindahkan ide, gagasan, dan perasaan ke dalam bahasa tulis yang mudah dipahami oleh pembaca.

Salah satu keterampilan menulis yang harus dikuasai oleh siswa dalam mata pelajaran Bahasa dan Sastra Indonesia ialah keterampilan menulis cerpen (cerita pendek). Siswanto (dalam Maghfiroh et. al., 2012:2) menyatakan bahwa cerpen merupakan bentuk prosa rekaan yang pendek Pendek di sini masih mempersyaratkan adanya keutuhan cerita, bukan asal sedikit halaman. Karena pendek, permasalahan yang digarap tidak begitu kompleks.

Menulis cerpen merupakan serangkaian kegiatan menulis yang dilakukan oleh seseorang untuk menghasilkan prosa fiksi berupa cerpen. Penulis cerpen yang baik tidak hanya memperhatikan keindahan bahasa, isi dan nilai-nilai kehidupan yang ada di lingkungan masyarakat juga harus menjadi bahan pertimbangan.

Cerpen terbentuk atas unsur-unsur pembangun yang saling berkaitan. Adanya keterkaitan antar unsur pembangun inilah yang akan menentukan cerpen tersebut sudah bagus atau belum. Unsur pembangun utama yang harus ada di dalam sebuah cerpen ialah unsur instirnsik yang terdiri atas tema, amanat, alur (plot), latar, penokohan, gaya bahasa, dan sudut pandang.

Cara yang dapat dilakukan penulis untuk menghasilkan cerpen yang berkualitas baik ialah dengan sering melakukan latihan menulis cerpen. Latihan yang dilakukan dengan giat dan berkesinambungan akan membuat siswa menjadi terbiasa dalam menuangkan ide, pikiran, gagasan, dan perasaannya dalam bentuk cerpen.

Selain itu, membaca karya fiksi juga mampu meningkatkan keterampilan siswa dalam menulis cerpen. Membaca karya fiksi berarti menikamati ceritanya, menghibur diri untuk memperoleh kepuasan batin. Menurut Nurhadi (2004:13), ketika pembaca ingin membaca karya fiksi, tujuan utama pembaca adalah memperoleh kenikmatan dari karya fiksi tersebut. Membaca karya fiksi membutuhkan sarana dan prasarana yang memadai misalnya dengan menyediakan karya fiksi di perpustakaan sekolah.

Berdasarkan observasi awal dan wawancara informal yang penulis lakukan dengan guru mata pelajaran Bahasa Indonesia di SMP Negeri 1 Kecamatan Kecamatan Pangkalan yang bernama Ibu Nelwati J, S. Pd., tanggal 2 Maret 2013 diperoleh tiga gambaran umum. Pertama, fasilitas buku di perpustakaan sekolah tidak memadai, terutama buku-buku yang bersifat fiksi. Kedua, siswa kesulitan dalam menuangkan ide, gagasan, dan perasaannya ke dalam bentuk tulisan, khususnya cerpen. Ketiga, kurangnya pemahaman siswa terhadap unsur-unsur pembangun karya fiksi. Permasalahan inilah yang menyebabkan siswa kesulitan dalam memahami karya fiksi yang dibacanya. Bahkan, hal ini juga menyebabakan turunnnya produktifitas siswa dalam menulis.

Berdasarkan hasil wawancara tersebut, penulis juga memperoleh informasi bahwa berdasarkan KKM yang telah ditetapkan sekolah, diperoleh informasi bahwa dari keseluruhan siswa SMP Negeri 1 Kecamatan Pangkalan yang memiliki nilai Bahasa dan Sastra Indonesia di atas KKM hanya $40 \%$.

Sehubungan dengan permasalahan yang telah dikemukakan sebelumnya, peneliti merasa perlu untuk melakukan penelitian mengenai hubungan keterampilan membaca fiksi dan keterampilan menulis cerpen di SMP Negeri 1 Kecamatan Pangkalan.

Penelitian ini memiliki tiga tujuan. Pertama, mendapatkan deskripsi mengenai keterampilan membaca fiksi siswa kelas IX SMP Negeri 1 Kecamatan Pangkalan. Kedua, mendapatkan 
deskripsi mengenai keterampilam menulis cerpen siswa kelas IX SMP Negeri 1 Kecamatan Pangkalan. Ketiga, menganalisis hubungan keterampila membaca fiksi dan keterampilan menulis cerpen siswa kelas IX SMP Negeri 1 Kecamatan Pangkalan.

\section{KAJIAN TEORITIS}

Menulis cerpen adalah serangkaian kegiatan yang dilakukan untuk mencurahkan ide, gagasan, dan perasaan secara tertulis dalam bentuk cerpen. Hal yang sangat penting dalam menulis cerpen ialah imajinasi penulis. Cerpen yang tidak diiringi dengan imajinasi yang indah akan membosankan untuk dibaca. Imajinasi ini disinergikan dengan realitas objektif atau kenyataan, sehingga dengan adanya imajinasi akan terciptalah sebuah cerpen yang menarik dan masuk akal. "Tanpa olah imajinasi, realitas objektif yang diolah menjadi cerpen, akan menjadi sebuah laporan (reportase) biasa yang mungkin lebih buruk dari reportase jurnalistik", (Thahar, 2004:115). Dengan kata lain, dapat disimpulkan bahwa sebuah cerpen yang baik adalah cerpen yang menggabungkan antara imajinasi dengan realitas objektif, sehingga pembaca akan terbawa dengan suasana dan peristiwa yang tergambar di dalam cerpen tersebut.

Selain oleh imajinasi, faktor lain yang perlu dipertimbangkan sebelum menulis cerpen adalah tokoh yang akan diceritakan dalam cerpen tersebut. Tokoh adalah salah satu unsur instrinsik yang menjadi pondasi sebuah cerpen. Menurut Sambodja (2007:31) "Salah satu pintu masuk dalam menulis cerpen adalah memilih tokoh yang akan menjadi tulang punggung cerpen. Dalam hal ini, pilihlah tokoh yang 'bermasalah' ".

Menurut Siswanto (dalam Maghfiroh et. al., 2012:2) "cerpen atau cerita pendek merupakan bentuk prosa rekaan yang pendek". Pendek di sini masih mempersyaratkan adanya keutuhan cerita, bukan asal sedikit halaman. Karena pendek, permasalahan yang digarap tidak begitu kompleks." Sebagai salah satu bentuk prosa rekaan, cerpen memiliki unsur-unsur pembangun cerpen yang biasanya disebut unsur intrinsik. Unsur intrinsik adalah unsur-unsur yang secara faktual akan dijumpai jika seseorang membaca cerpen. Dalam hal ini, membaca fiksi sama halnya dengan membaca pemahaman. Agar pesan yang ingin disampaikan penulis dalam karya fiksi tersebut dapat ditangkap oleh para pembaca, pembaca dituntut untuk memahami isi bacaan fiksi yang dibacanya. Pemahaman ini tidak akan didapatkan oleh pembaca jika pembaca tidak mengetahui unsur-unsur yang membangun karya fiksi tersebut.

Berdasarkan uraian tentang membaca fiksi tersebut, dapat diambil kesimpulan bahwa membaca fiksi adalah kegiatan membaca karya fiksi guna menangkap pesan atau nilai moral yang disampaikan oleh penulis di dalam karya fiksi tersebut. Selain itu, membaca fiksi juga bertujuan agar pembaca atau penikmat karya fiksi dapat memperoleh kepuasan batin dan hiburan dari karya fiksi yang dibacanya.

\section{METODE PENELITIAN}

Jenis penelitian ini adalah kuantitatif dengan desain korelasional. Metode yang digunakan dalam penelitian ini ialah metode deskriptif analisis. Pada penelitian ini, metode deskriptif analisis bertujuan menggambarkan dan menganalisis hubungan antara keterampilan membaca fiksi dan keterampilan menulis cerpen siswa kelas IX SMP Negeri 1 Kecamatan Pangkalan. Populasi dalam penelitian ini adalah siswa kelas IX SMP Negeri 1 Kecamatan Pangkalan yang terdaftar pada tahun ajaran 2013/2014 dengan jumlah siswa 164 orang. Penarikan sampel pada penelitian ini dilakukan dengan menggunakan teknik Proportional 
Random Sampling. Penarikan sampel dilakukan berdasarkan jumlah siswa per kelas, penarikan sampel dilakukan secara acak. Arikunto (2006:134) menyatakan apabila subjek penelitian kurang dari 100, maka sampel lebih baik diambil semuanya. Namun, apabila jumlah subjek penelitian lebih dari 100, maka subjek yang diambil sebanyak 10-15\% atau $20-25 \%$ atau lebih. Penarikan sampel diambil sebanyak $20 \%$ dari jumlah siswa per kelas yakni sebanyak 34 orang.

Data yang akan diperoleh dalam penelitian ini ialah data kuantitatif. Data keterampilan membaca fiksi diperoleh dari skor hasil tes objektif dan data keterampilan menulis cerpen diperoleh dari skor hasil tes unjuk kerja.

Instrumentasi yang digunakan dalam penelitian ini ialah tes objektif tipe pilihan ganda dan tes unjuk kerja. Tes objektif digunakan untuk mengukur keterampilan membaca fiksi siswa dan tes unjuk kerja digunakan untuk mengukur keterampilan menulis cerpen siswa. Sebelum tes dilaksanakan terlebih dahulu dilakukan uji coba instrumen kepada siswa di luar sampel.

\section{HASIL DAN PEMBAHASAN}

Langkah yang dilakukan untuk mengetahui gambaran mengenai keterampilan membaca fiksi siswa kelas siswa kelas IX SMP Negeri 1 Kecamatan Pangkalan ialah dengan menghitung skor mentah dari jawaban yang benar kemudian skor tersebut diubah menjadi nilai dengan menggunakan rumus persentase. Kemudian, dikelompokkan ke dalam masing-masing indikator penilaian yang sudah ditetapkan. Setelah itu, nilai tersebut dimasukkan ke dalam tabel keterampilan membaca fiksi secara keseluruhan.

\section{Pengelompokkan Keterampilan Membaca Fiksi Siswa Kelas IX SMP Negeri 1 Kecamatan Pangkalan Secara Keseluruhan}

\begin{tabular}{|c|c|c|c|c|}
\hline No. & Rentang Nilai & Kualifikasi & Frekuensi & Persentase \\
\hline 1 & $96-100 \%$ & Sempurna & 0 & 0 \\
\hline 2 & $86-95 \%$ & Baik sekali & 0 & 0 \\
\hline 3 & $76-85 \%$ & Baik & 2 & 5,88 \\
\hline 4 & $66-75 \%$ & Lebih dari cukup & 14 & 41,17 \\
\hline 5 & $56-65 \%$ & Cukup & 10 & 41,66 \\
\hline 6 & $46-55 \%$ & Hampir Cukup & 8 & 23,52 \\
\hline 7 & $36-45 \%$ & Kurang & 0 & 0 \\
\hline 8 & $26-35 \%$ & Kurang sekali & 0 & 0 \\
\hline 9 & $16-25 \%$ & Buruk & 0 & 0 \\
\hline 10 & $0-15 \%$ & Buruk sekali & 0 & 0 \\
\hline \multicolumn{5}{|c|}{ Jumlah } \\
\hline
\end{tabular}

Berdasarkan hasil penelitian dan analisis data dapat diketahui bahwa keterampilan membaca fiksi siswa kelas IX SMP Negeri 1 Kecamatan Pangkalan terbagi atas empat kualifikasi yaitu baik, lebih dari cukup, cukup, dan hampir cukup. Rata-rata keterampilan membaca fiksi siswa secara keseluruhan ialah 61,42 dengan kualifikasi cukup berada pada rentangan 56-65\%. Kriteria Ketuntasan Minimum (KKM) kelas IX SMP Negeri 1 Kecamatan Pangkalan untuk mata pelajaran Bahasa dan Sastra Indonesia adalah 75. Jika
KKM tersebut 
dibandingkan dengan rata-rata keterampilan membaca fiksi dapat disimpulkan bahwa secara keseluruhan keterampilan siswa dalam membaca fiksi berada di bawah KKM. Dengan demikian dapat dinyatakan bahwa keterampilan membaca fiksi siswa tergolong rendah.

Dari tujuh indikator keterampilan membaca fiksi, indikator yang paling dikuasai siswa adalah indikator keempat yaitu keterampilan menentukan latar. Rata-rata nilai yang diperoleh siswa adalah 84,32 dengan kualifikasi baik berada pada rentangan $76-85 \%$. Unsur latar dapat dibedakan menjadi tiga bagian yaitu tempat, waktu, dan sosial (Nurgiyantoro, 2010:227). Pendapat yang hampir sama juga disampaikan Priyatni (2010:112) yang menyatakan bahwa latar tidak hanya berupa tempat, waktu, yang bersifat fisik semata, tetapi juga setting dengan tempat, waktu, situasi dan bendabenda atau lingkungan hidup yang berfungsi membuat cerita menjadi logis. Berdasarkan rata-rata nilai tersebut dapat dikatakan bahwa siswa mampu memahami latar dengan baik. Hal ini dibuktikan dengan mudahnya siswa dalam menentukan unsur-unsur latar, baik berupan tempat, waktu, maupun lingkungan sosial di kutipan prosa fiksi. Selain itu, siswa juga memahami konsep latar dengan baik.

Penguasaan siswa yang paling rendah terdapat pada indikator ketiga yaitu menentukan alur. Hal ini dibuktikan dengan perolehan rata-rata nilai 38,87 dengan kualifikasi kurang berada pada rentangan 36-45\%. Kesulitan siswa dalam menentukan alur prosa fiksi disebabkan karena siswa kurang paham dengan konsep alur dan rumitnya penggambaran alur. Alur sebagai peristiwa yang ditampilkan di dalam cerita tidaklah bersifat sederhana. Hal ini disebabkan karena penulis menyusun peristiwa-peristiwa dalam cerita berdasarkan sebab akibat (Kenny dalam Nurgiyantoro, 2010:113).

Berdasarkan rata-rata nilai tersebut dapat dikatakan siswa kurang memahami konsep alur dengan baik. Hal inilah yang kemudian menyebabakan siswa kesulitan dalam mengidentifikasi alur yang terdapat di dalam karya fiksi.

Data keterampilan menulis cerpen didapat dengan memberikan tes menulis cerpen kepada siswa. Sama halnya dengan keterampilan membaca fiksi, keterampilan menulis cerpen juga diolah dengan menggunakan rumus persentase. Data keterampilan menulis cerpen dinilai oleh dua orang yaitu peneliti dan penimbang yang selanjutnya akan disebut penilai satu (P1) dan penilai dua (P2). Tulisan siswa dibaca dengan cermat kemudian diberi skor sesuai rentangan skor yang telah ditetapkan. Kemudian skor tersebut diubah menjadi nilai. Nilai yang telah ada dikelompokkan berdasarkan indikator penilaian keterampilan menulis cerpen. Setelah itu, nilai tersebut dimasukkan ke dalam tabel keterampilan menulis cerpen.

Tabel 2

\section{Pengelompokkan Keterampilan Menulis Cerpen Siswa Kelas IX SMP Negeri 1 Kecamatan Pangkalan Secara Keseluruhan}

\begin{tabular}{|c|c|c|c|c|}
\hline No. & Rentang Nilai & Kualifikasi & Frekuensi & Persentase \\
\hline $\mathbf{1}$ & $\mathbf{2}$ & $\mathbf{3}$ & $\mathbf{4}$ & $\mathbf{5}$ \\
\hline 1 & $96-100 \%$ & Sempurna & 0 & 0 \\
\hline 2 & $86-95 \%$ & Baik sekali & 0 & 0 \\
\hline 3 & $76-85 \%$ & Baik & 5 & 14,70 \\
\hline 4 & $66-75 \%$ & Lebih dari cukup & 3 & 8,82 \\
\hline
\end{tabular}




\begin{tabular}{|c|c|c|c|c|}
\hline 5 & $56-65 \%$ & Cukup & 15 & 44,11 \\
\hline 6 & $46-55 \%$ & Hampir Cukup & 8 & 23,52 \\
\hline 7 & $36-45 \%$ & Kurang & 3 & 8,82 \\
\hline 8 & $26-35 \%$ & Kurang sekali & 0 & 0 \\
\hline 9 & $16-25 \%$ & Buruk & 0 & 0 \\
\hline 10 & $0-15 \%$ & Buruk sekali & 0 & 0 \\
\hline \multicolumn{3}{|c|}{ Jumlah } & 34 & 100 \\
\hline
\end{tabular}

Berdasarkan konversi skala sepuluh, keterampilan menulis cerpen siswa kelas IX SMP Negeri 1 Kecamatan Pangkalan dapat dikelompokkan menjadi empat kategori sebagai berikut. Pertama, siswa yang berada pada tingkat penguasaan $(76-85 \%)$ kualifikasi baik berjumlah 5 orang $(14,70 \%)$. Kedua, siswa yang berada pada tingkat penguasaan $(66-75 \%)$ kualifikasi lebih dari cukup berjumlah 3 orang $(8,82 \%)$. Ketiga, siswa yang berada pada tingkat penguasaan (56-65\%) kualifikasi cukup berjumlah 15 orang $(44,11 \%)$. Keempat, siswa yang berada pada tingkat penguasaan (46- 55\%) kualifikasi hampir cukup berjumlah 8 orang $(23,52 \%)$. Kelima, siswa yang berada pada tingkat penguasaan kurang (36$45 \%)$ berjumlah 3 orang $(8,82 \%)$. Berdasarkan hasil penelitian dan analisis data diketahui bahwa keterampilan menulis cerpen siswa kelas IX SMP Negeri 1 Kecamatan Pangkalan terbagi atas lima kualifikasi yaitu baik, lebih dari cukup, cukup, dan hampir cukup, dan kurang. Rata-rata keterampilan membaca fiksi siswa secara keseluruhan adalah 60,37 dengan kualifikasi cukup berada pada rentangan 56-65\%.

Kriteria Ketuntasan Minimum (KKM) kelas IX SMP Negeri 1 Kecamatan Pangkalan untuk mata pelajaran Bahasa dan Sastra Indonesia adalah 75. Jika KKM tersebut dibandingkan dengan rata-rata keterampilan menulis cerpen, dapat disimpulkan bahwa secara keseluruhan keterampilan siswa dalam menulis cerpen berada di bawah KKM. Dengan demikian dapat dinyatakan bahwa keterampilan menulis cerpen siswa tergolong rendah. Dari tujuh indikator keterampilan menulis cerpen, indikator yang paling dikuasai siswa ialah sudut pandang.

Rata-rata nilai yang diperoleh siswa adalah 99,41 dengan kualifikasi sempurna berada pada rentangan 96$100 \%$. Sudut pandang yang banyak digunakan siswa ialah sudut pandang narator (pencerita) orang pertama pelaku utama. Penggunaan sudut pandang orang pertama pelaku utama ini sesuai dengan tuntutan $\mathrm{KD}$ yang mengharapkan siswa mampu menulis cerpen berdasarkan peristiwa yang pernah dialami. Penggunaan sudut pandang orang pertama pelaku utama umumnya digunakan dalam mengisahkan peristiwa dan tindakan yang diketahui, dilihat, didengar, dialami, dan dirasakan langsung oleh narator (Nurgiyantoro, 2010:262). Sama halnya denga Sayuti (2000:160) yang menyatakan bahwa sudut pandang orang pertama pengarang secara langsung terlibat di dalam cerita.

Berdasarkan hasil deskripsi dan analisis data dapat disimpulkan bahwa terdapat hubungan yang signifikan antara keterampilan membaca fiksi dengan keterampilan menulis cerpen siswa kelas IX SMP Negeri 1 Kecamatan Pangkalan pada taraf signifikansi $95 \%$ pada derajat kebebasan n-2 (34-2=32). Dengan demikian, $\mathrm{H} 0$ ditolak dan $\mathrm{H} 1$ diterima karena hasil pengujian membuktikan bahwa thitung lebih besar dari ttabel yaitu $1,97>1,70$. Jadi, dapat disimpulkan bahwa keterampilan membaca fiksi sangat membantu siswa dalam menulis cerpen. 


\section{PENUTUP}

Berdasarkan hasil pengolahan data dan pembahasan hasil penelitian mengenai hubungan keterampilan membaca fiksi dengan keterampilan menulis cerpen siswa kelas IX SMP Negeri 1 Kecamatan Pangkalan maka diperoleh hasil sebagai berikut. Pertama, keterampilan membaca fiksi siswa kelas IX SMP Negeri 1 Kecamatan Pangkalan berada pada kualifikasi cukup $(61,42)$. Kedua, keterampilan menulis cerpen siswa kelas IX SMP Negeri 1 Kecamatan Pangkalan juga berada pada kualifikasi cukup (60,37). Ketiga, terdapat hubungan yang signifikan antara keterampilan membaca fiksi dengan keterampilan menulis cerpen siswa kelas IX SMP Negeri 1 Kecamatan Pangkalan. Berdasarkan hasil penelitian dan kesimpulan, dapat diberikan saran-saran sebagai berikut. Pertama, guru Bahasa dan Sastra Indonesia di SMP Negeri 1 Kecamatan Pangkalan diharapkan lebih meningkatkan keterampilan siswa dalam membaca dan memahami karya sastra, seperti prosa fiksi untuk mendukung siswa dalam menulis cerpen dan memperbanyak latihan menulis cerpen. Kedua, untuk meningkatkan keterampilan siswa dalam membaca fiksi dan keterampilan menulis cerpen diharapkan pihak sekolah menyediakan sarana dan prasarana, memperbanyak koleksi buku- buku yang bersifat sastra di perpustakaan serta mengadakan ekstrakurikuler yang dapat mengembangkan minat dan bakat siswa dalam bersastra. Ketiga, siswa diharapkan agar lebih menyadari pentingnya membaca karya satra. Keempat, untuk meningkatkan keterampilan dalam menulis dan menghasilkan cerpen yang baik, maka terlebih dahulu ditingkatkan keterampilan membaca dan memahami prosa fiksi.
DAFTAR PUSTAKA

Arikunto, Suharsimi. 2006. Prosedur Penelitian: Suatu Pendekatan Praktek. Jakarta: Rineka Cipta.

Magfiroh et al. 2012. "Pengembangan Bahan Ajar Memahami Cerpen dengan Adaptasi Strategi SQ3R untuk Siswa Kelas X SMA". Bahasa dan Seni Universitas Negeri Malang. Volume 1. Hlm: $1-11$.

Nurgiyantoro, Burhan. 2010. Teori Pengkajian Fiksi. Yogyakarta: Gadjah Mada University Press.

Nurhadi. 2004. Bagaimana Meningkatkan Kemampuan Membaca?: Suatu Teknik Memahami Literatur dengan Efisien. Malang: Sinar Batu Algensindo.

Priyatni, Endah Tri. 2010. Membaca Sastra dengan Ancangan Literasi Kritis. Jakarta: Bumi Aksara.

Sayuti, A. Suminto. 2000. Berkenalan dengan Prosa Fiksi. Yogyakarta: Darma Media.

Semi, M. Atar. 2007. Dasar-dasar Keterampilan Menulis. Bandung: Angkasa.

Tarigan, Henry Guntur. 2008. Menulis Sebagai Suatu Keterampilan Berbahasa. Bandung: Angkasa. 